bacterium fortuitum colonization from a contaminated ice machine. Am Rev Respir Dis 1988;138:891-894.

5. DuMoulin GC, Stottmeier KD, Pelletier PA, Tsang AY, HedleyWhite J. Concentration of Mycobacterium avium by hospital hot water systems. JAMA 1988;260:1599-1601.

6. Lockwood WW, Friedman C, Bus N, Pierson C, Gaynes R. An outbreak of Mycobacterium terrue in clinical specimens associated with a hospital potable water supply. Am Rev Respir Dis 1989;140:1614-1617.

7. Weinberger M, Berg SL, Feuerstein IM, Pizzo PA, Witebsky FG. Disseminated infection with Mycobacteriumgordonae: report of a case and a critical review of the literature. Clin Infect Dis 1992;14:1229-1239.

8. Lowry PW, Beck-Sague CM, Bland LA, et al. Mycobacterium chelonae infection among patients receiving high-flux dialysis in a hemodialysis clinic in California. J Infect Dis 1990;161:85-90.

9. Costrini AM, Mahler DA, Gross WM, Hawkins JE, Yesner R, D'Esopo ND. Clinical and roentgenographic features of nosocomial pulmonary disease due to Mycobacterium xenopi. Am Rev Respir Dis 1981;123:104-109.

10. Lowry PW, Jarvis WR, Oberle $A D$, et al. Mycobacterium chelonae causing otitis media in an ear, nose, and throat practice. $N$ Engl $J$ Med 1988;319:978-982.

11. American Thoracic Society. Diagnosis and treatment of disease caused by nontuberculous mycobacteria. Am Rev Respir Dis 1990;142:940-953.

12. Floyd MM, Silcox VA, Jones WD Jr., Butler WR, Kilburn JO. Separation of Mycobacterium bovis BCG from Mycobacterium tuberculosis and Mycobacterium bovis by using highperformance liquid chromatography of mycolic acids. $J$ Clin Microbiol 1992;30:1327-1330.

13. Simor AE, Salit IE, Vellend H. The role of Mycobacterium xenopi in human disease. Am Rev Respir Dis 1984;129:435-438.

14. Weinberg JR, Gertner D, Dootson G, et al. Disseminated
Mycobacterium xenopi infection. Lancet 1985;1:1033-1034.

15. Gross WM, Hawkins JE, Murphy DB. Origin and significance of Mycobacterium xenopi in clinical specimens. Bulletin of the International Union of Tuberculosis 1976;51:267-269.

16. Garner JS, Favero MS. Guidelines for Handwashing and Hospital Environmental Control, 1985. Atlanta, GA: Centers for Disease Control and Prevention, 1985. U.S. Department of Health and Human Services publication 99-1117.

17. Fraser VJ, Jones M, Murray PR, Medoff G, Zhang Y, Wallace RJ Jr. Contamination of flexible fiberoptic bronchoscopes with Mycobacterium chelonae linked to an automated bronchoscope disinfection machine. Am Rev Respir Dis 1992;145:853-855.

18. Kent PT, Kubica GF! Public Health Mycobacteriology: A Guide for the Level III Laboratory. Atlanta, GA Centers for Disease Control and Prevention; 1985.

19. Hanrahan JP, Morse DL, Scharf VB, et al. A community hospital outbreak of legionellosis transmission by potable hot water. Am J Epidemiol 1987;125:639-649.

20. Beck-Sague CM, Jarvis WR, Bland IA, Arduino MJ, Aquero SM, Verosic G. Outbreak of gram negative bacteremia and pyrogenic reactions in a hemodialysis center. Am J Nephrol 1990;10:397403.

21. Pegues D, Arathoon B, Samayoa B, et al. Epidemic gram negative bacteremia in neonates in a neonatal intensive care unit, Guatemala. In: Program and Abstracts of the 31st Interscience Conference on Antimicrobial Agents and Chemotherapy. Chicago, Illinois: American Society for Microbiology; 1991. Abstract no. 353.

22. Baptiste MS. Preventing tap water burns. Am J Public Health 1980;70:727-729.

23. Katcher ML. Scald bums from hot tap water. JAMA 1981;46:12191222.

\title{
CDC Publishes Revised Draft Guidelines for Preventing Transmission of Tuberculosis
}

The Centers for Disease Control and Prevention (CDC) has released the long-awaited "Draft Guidelines for Preventing the Transmission of Tuberculosis in Health-Care Facilities, Second Edition" (Federal Register, 58: 195, part 2; 58 FR 52810, Tuesday, October 12, 1993).

Interested parties may file written comments on the draft docu- ment on or before December 13, 1993. Comments on the draft guidelines should be in writing and addressed to the Centers for Disease Control and Prevention, Attention: Guidelines Work Group, Mailstop E07, 1600 Clifton Rd. NE., Atlanta, GA 30333. To facilitate review, you should categorize your comments as follows: (1) Risk Assessment, (2) Administrative
Controls, (3) Engineering Controls, (4) Respiratory Protection, (5) Education and Training, (6) HCW Counseling, Screening, and Evaluation, (7) Cost and Feasibility of Implementation, and (8) Other. For further information, contact Carmine Bozzi at (404) 6398027. 